chairman of the National Research Council's Committee on Mathematical Tables and Aids to Computation, to whose retiremenv from the chair of mathematics at Brown University reference was made in Nature of August 21, p. 211. Some of the articles are bibliographical, such as one in the second number (April 1943) dealing with the various trigonometric tables with radian arguments. A valuable feature is a section on the description and location of unpublished tables. This, it is hoped, will not only help research workers, but also prevent useless duplication of costly effort. There is a section for queries and replies to them. The longest article in the first number is a list of eighty-eight recent tables, with reviews of the last fourteen and references to other journals where reviews of the first seventy. four can be found.

\section{Earthquakes during June}

DurnNg June 1943 thirteen earthquakes were registered strongly by the seismographs at Kew Observatory. The strongest of these was on June 9. The shock began registration with iP at $03 \mathrm{~h} .19 \mathrm{~m}$. 56s. U.T. and attained a maximum amplitude of $420 \mu$ at $04 \mathrm{~h} .09 \mathrm{~m} .55 \mathrm{~s}$. U.T. on the vertical component at Kew. It is estimated to have come from an epicentre some $10,700 \mathrm{~km}$. distant. This earthquake was registered at Stonyhurst at $03 \mathrm{~h} .20 \mathrm{~m}$. $40 \mathrm{~s}$. U.T., beginning with $e P$. Three shocks were registered at Kew and Stonyhurst on June 13. The first was by far the greatest. It recorded $i P$ on all three components at Kew at 05 h. $23 \mathrm{~m}$. 59s. U.T., apparently coming from an epicentre some $9,100 \mathrm{~km}$. distant. The first recording was compressional and the maximum amplitude at Kew was $270 \mu$ at $06 \mathrm{~h} .00 \mathrm{~m}$. $45 \mathrm{~s}$. U.T. on the $N$ component. Stonyhurst recorded the shock at 05h. $24 \mathrm{~m}$. 10s. U.T. The other two shocks on June 13 were probably aftershocks from the same epicentre. The German News Agency reported a shock on June 12 , recorded at Württemberg Observatory at 6.22 a.m., and believed to have taken place in the Eastern Alps, but this movement was not significantly recorded at Kew.

The United States Coast and Geodetic Survey, in co-operation with Science Service and the Jesuit Seismological Association, has determined the epicentres of three earthquakes in mid-June on the basis of instrumental reports received from observatories in America, Australia and New Zealand. The first was on June 13 at $5 \mathrm{~h} .11 \mathrm{~m}$. 44s. U.T. from an epicentre near $43^{\circ} \mathrm{N}$., $142^{\circ} \mathrm{E}$., which is near the central peak of Hokkaido Island, one of the Japanese Islands. The depth of focus was normal. The second was on June 14. The earthquake took place at 13h. 23m. 34s. U.T. at an epicentre near latitude $28.5^{\circ} \mathrm{N}$., longitude $112^{\circ} \mathrm{W}$., which is in the Gulf of California just south of the mouth of the Sonora River. The depth of focus was normal. The third earthquake was on June 15 , occurring at $18 \mathrm{~h} .21 \cdot 7 \mathrm{~m}$. U.T. from an epicentre near latitude $14.5^{\circ} \mathrm{N}$., longitude $93^{\circ} \mathrm{W}$., which is in the Pacific Ocean on the 100-fathom line west of the junction between Chiapas and Guatemala in Central America. This earthquake also had a normal depth of focus. The earthquake of June 20 was recorded at Kew and Stonyhurst. At Kew it recorded with iP at $15 \mathrm{~h} .38 \mathrm{~m}$. $04 \mathrm{~s}$. U.T. from an epicentre some $2,600 \mathrm{~km}$. distant. It attained a maximum amplitude at Kexp of $98 \mu$ at 15h. $48 \mathrm{~m}$. 36s. U.T. on the vertical component. All interpretations and calculations are provisional.

\section{Gift by Prof. T. D. A. Cockerell}

Prof. T. D. A. CockerelL, emeritus professor of zoology in the University of Colorado, will be remembered by many readers of NATURE as a frequent contributor of communications on biological topics. So long ago as 1920, he produced a useful and distinctive book entitled "Zoölogy: A Text-book for Colleges and Universities", which was reviewed in NATURE of December 23, 1920, p. 529. This was not an ordinary text-book of its time, for it catered for the needs of those who were not intending to specialize in zoology, and so included chapters on social life, the evolution of man, eugenics and sociology from the biologist's point of view. In its general approach it was perhaps in advance of much of the thought of its day. The book was re-issued from time to time, and Prof. Cockerell has now had prepared, at his own expense, an impression of a thousand copies which have been presented to the Board of Education in Great Britain. The gift will be much appreciated, and the volumes will no doubt contribute in no small measure to the growth of that biological outlook on man and his affairs which are necessary for the future peace of the world.

\section{The Night Sky in October}

FULl moon occurs on October 13d. 13h. 23m. U.T., and new moon on October 27d. 15h. $23 \mathrm{~m}$. The following conjunctions with the moon take place: Oct. 18d. 04h., Mars $4^{\circ}$ N. ; Oct. 18d. 14h., Saturn $2^{\circ}$ N.; Oct. 23 d. 07 h., Jupiter $0.2^{\circ}$ S. ; Oct. 25d. 03h., Venus $4^{\circ} \mathrm{S}$. The following occultations of stars brighter than magnitude 6 take place : Oct. 3 d. $18 \mathrm{~h}$. $01 \cdot 0 \mathrm{~m}$., $49 \mathrm{Lib}(D)$; Oct. $8 \mathrm{~d}$. 18h. $43 \cdot 5 \mathrm{~m} ., 19 \mathrm{Cap}(D)$; Oct. 15d. 02h. 59.2m., $\mu \operatorname{Cet}(D) ;$ Oct. 15d. 04h. 10.3m., $\mu$ Cet $(R)$; Oct. 15d. 22h. 17.4m., $f$ Tau $(D)$; Oct. 15d. $22 \mathrm{~h}$. 58.6m., $f \operatorname{Tau}(R)$; Oct. $17 \mathrm{~d}$. 0Ih. $26 \cdot 5 \mathrm{~m}$., $\gamma \operatorname{Tau}(R)$. The times are given for Greenwich and $D$ and $R$ refer to disappearance and reappearance respectively. Mercury attains its greatest western elongation on Oct. 10. It is a morning star, and at the beginning of the month rises at 5h., an hour before sunrise. At the end of the month it rises at $6 \mathrm{~h} .15 \mathrm{~m} ., 35$ minutes before sunrise. Venus is a morning star and rises at $3 \mathrm{~h} .17 \mathrm{~m}$. and $2 \mathrm{~h} .37 \mathrm{~m}$. at the beginning and end of the month respectively. The planet attains its greatest brilliancy on Oct. 13. Mars can be seen in the constellation of Taurus in the evening and sets at $12 \mathrm{~h}$. $32 \mathrm{~m}$. at the beginning of the month and at $11 \mathrm{~h} .05 \mathrm{~m}$. at the end of the month. On Oct. 28 the planet is stationary. Jupiter, in the constellation of Leo, is a morning star, rising at 1h. $30 \mathrm{~m}$, at the beginning of the month and at midnight at the end of the month. Saturn can be seen close to Mars and is stationary on Oct. 9. At the beginning and end of the month the planet sets at $12 \mathrm{~h} .40 \mathrm{~m}$. and $11 \mathrm{~h} .10 \mathrm{~m}$. respectively. Times are given approximately for the latitude of Greenwich. The Orionid meteor shower is due about Oct. 18-21. The radiant is close to the star $\vee$ Orionis.

\section{Announcements}

Prof. Edward Hindle, regius professor of zoology in the University of Glasgow, has been appointed scientific director of the Zoological Society of London.

THe following appointments and promotions in the Colonial Service have recently been made: J. D. Yeld, agricultural officer, Northern Rhodesia; T. Threlkeld (veterinary officer, Jamaica), senior veterinary officer, Jamaica. 